\title{
Comparative Study of Time Use Pattern in Pre and Post-Harvesting Activities in Himalayan Belt of North India
}

\author{
Afsah Iqbal Nahvi ${ }^{1 *}$, Adnan Abubakr², Qurazaah Akeemu ${ }^{1}$, \\ Tauseef A. Wani ${ }^{3}$, Mudasir Kirmani ${ }^{2}$, Poonam Sharma ${ }^{1}$ and Ruchi Thakur ${ }^{4}$ \\ ${ }^{1}$ Division of FST, Faculty of Horticulture, SKUAST-K, India \\ ${ }^{2}$ Division of AEM, Faculty of fisheries, SKUAST-K, India \\ ${ }^{3}$ Krishi Vigyan Kendra, ETC Malangpora, SKUAST -K, India \\ ${ }^{4}$ GDC, Samba, District Coordinator, MSK, Doda, India \\ *Corresponding author
}

\section{Keywords \\ Rural, Farmwomen, Farm activities, Sowing, Weeding, Time use \\ Article Info \\ Accepted: \\ xx November 2020 \\ Available Online: \\ xx December 2020}

\section{A B S T R A C T}

The study was undertaken at Kunzer village located in the district Baramulla of Kashmir valley as Baramulla is known as one of the major paddy areas of the Kashmir valley A sample of 100 women who were actively involved in rice cultivation were selected. It was observed that maximum number of the farm women belonged to age group of 25-45 years and were illiterate. Majority of respondents live in joint family system comprising $46 \%$ and possess $5-10$ kanal of paddy land. It was observed that respondents mostly (36\%) having 6-9 members in their family. The activities performed by them included pre- and post-harvesting activities; where cleaning of boundaries, collecting stubbles, preparation of nursery, seed cleaning and treatment, Sowing, pulling out seedlings, transplanting and weeding were counted in Pre-harvesting activities. Harvesting was also found to be one of the major activities, performed by almost all the farm women. Post harvesting activities includes bundling, threshing, winnowing, bagging, stocking, storing and transportation of the paddy to safe place. The paddy is then required to be guarded in which the farm women participated equally. During the study it was observed that maximum of farmwomen $(71 \%)$ work to collect stubbles and spend more than 4 hours a day in shift one. Similarly, women $(41 \%, 61 \%$ and $52 \%)$ spent more than 4 hours a day in nursery preparation, seed cleaning and seed treatment respectively. Sowing is performed by $37 \%$ of respondents for more than 4 hours a day. Pulling out of seedlings is done by almost all the participants, $76 \%$ of respondents perform the said activity for more than 4 hours a day. Similarly, transplanting of seedlings is done by all the participants for more than 4 hours a day. Harvesting is energy and time-consuming activity and is performed by majority of farm women for more than 4 hours a day. Bundling (60\%) and bagging (49\%) activity was carried for more than 4 hours a day during shift one. Threshing and winnowing was carried out by $47 \%$ and stocking by $62 \%$ of the respondents for 2-4 hrs a day during shift one. Storing was carried out by $41 \%$ of the farm women for more than $4 \mathrm{hrs}$ a day. Observations were made that $54 \%$ of the farmwomen received help by their husbands in farming and $71 \%$ of the respondents perform the last activity that is transportation. Finally, results show that overall farmwomen spent 6 hours a day in preharvesting activities, working for more than 4 hours during a shift. Whereas, during post harvesting season farmwomen work for 7 hours a day during in the fields. The workload gets increased during harvesting season. 


\section{Introduction}

The crops were initially domesticated by the women, hereby the art and science of farming came into existence (Swaminathan, 2006). Farming is carried out by $86 \%$ of rural women, either as cultivator or agriculture labourer. An assessment in the Indian Himalaya state that a pair of bullock work for 1064 hours, a man for 1212 hours but a woman for 3485 hours in a farm of one hectare per year. Farm women in India perform all the farm related activities like arranging farm inputs and marketing of produce except ploughing and cart driving. Since years women have been working in the farm and provide help in raising and rearing the families hence it's a well-known acknowledged fact that farm women form the backbone of farming community all over the world. The importance of rural women in building country's economy, and towards food security sectors is clearly visible. The major activities farm women does include production of agricultural crops, preparations of meals, tending of domestic animals, taking care of family members, and maintenance of their homes. These activities usually are not accepted as "economically active work" but are essential for the wellbeing and economic development of our rural households. Farmwomen are found to be stressed as they have over burdened household work, farm non-farm income generating activities (Labao and Meyer, 1995). The statistical data shows the importance of the contribution of the farm women about their role in agriculture and allied sector but has been ignored. Kishtwaria et al (2009) has stated that the work of farm women is considered as non-productive, unorganised and undocumented globally. Rural women relatively work more in postharvest activities than that of pre-harvest activities. It is notable that in spite of their great contribution in the farm activities, their recognition as "worker" is yet not acknowledged. Farm women play an vital role in agricultural economy and development and their role in agriculture has still not been recognised in India. Farm women are still invisible workers with great contribution. In middle class families, women are involved in domestic tasks, childcare management, but the present Scenario of women has changed now, they perform other tasks also along with the basic role. Some women serve in various occupations as of 2018. Studies have shown that more than 75 percent women are involved in farm activities such as crop management, sowing, winnowing, weeding, threshing and cleaning of farm. The physical stress of farm women is much more than male because of heavy work load done by them in agriculture (Sing \&Vinay, 2013). According to World Bank (2011), women does 66\% of the world's work, produce $50 \%$ contribute in the food production, but earn $10 \%$ of the income and own only $1 \%$ of the property. Women represent $49.6 \%$ of the total population globally, but only $40.8 \%$ of the total workforce is in the formal sector. Among families with low socio-economic conditions and involved in paddy cultivation women work more than male. Hence, it becomes imperative to study about the time use and the involvement of farm women in agricultural sector. The paper presents time use participation of farmwomen during preand post-harvesting activities carried out in Kunzer area of Kashmir with an objective to study about the participation of women in pre and post-harvest activities of paddy.

\section{Materials and Methods}

The present study was carried out in chukar and batapora (50 from each) village of block Kunzer and district Baramulla, as it is the major rice belt of valley Kashmir. Total sample of 100 farm women was selected within reproductive age group of 25-45 years and actively involved in farm activities. 
Activities of the sample group was observed deeply and studied along with a co observer. A 24-hour time use diary was used to calculate their time use pattern of farm activities and direct observation was also carried out side by side. The activities done were recorded along with their time, frequency and duration. The data collected was analysed using appropriate statistical techniques (SPSS 12) and presented in form of tables and figures.

\section{Results and Discussion}

Figure no. 1 indicates that $46 \%$ being majority of respondents belong to joint families while as, $40 \%$ of the farmwomen belong to extended families, $14 \%$ to nuclear families. The work load increases as per the increase in the number of family members, however, in joint families the relatives sometimes provide help and reduce the work pressure.

The table no.1 shows that the average age of the sample was 31 years and belonged to age group 20-40 years.

Figure. 2 gives information about total and paddy land holdings of the farm women. Majority of farm women (34\%) have 10-20 kanal of land holding while as, $28 \%$ of farmwomen have 20 kanal of land holding. Further findings show that $28 \%$ rural women have above $20 \mathrm{Kanal}$ of land holding. It was observed that majority of respondents $(46 \%)$ have 5-10 Kanals of paddy.

The area of paddy fields has a direct impact on work pressure of farm women and the farm activity is directly dependent on the area of paddy land. It's quite clear that more the land area, more will be the production of paddy hence, more time and energy consumed in the farm activities. The reason being low socio-economic conditions and difficulty for sustaining their families. They overburden themselves by agricultural work and that too in low paying, less skilled and monotonous activities as reported by Bala (2010).

It is clearly depicted in table no.2 that majority of farm women $(36 \%)$ have 3-6 family members followed by $23 \%$ who had $3-$ 6 family members. Only $20 \%$ of farm women have 11 and more family members. Average age of children was found to be 2.26 within sample group. Majority of farmwomen (62\%) had 1-2 no of children followed by $24 \%$ who have 2-3 children while $14 \%$ of respondents had 3-4 numbers of children.

Figure no. 3 gives the information about the source of income. It was seen that agriculture was the main source of income among majority of respondents $(71 \%)$. It is clear from the present study that women play an vital role for improvement of their family economy and henceforth also prove as a main pillar to improve the economic status at national level too.

Figure no. 3 gives clearly depicts that $60 \%$ of farmwomen go to farm between 9-10 am, $25 \%$ of farmwomen reach farm between 8-9 am and only $15 \%$ of them go to farm between 10- $11 \mathrm{am}$.

The Table. 3 gives detailed information about time spent on the activity collecting stubbles by farmwomen. The data reveals that most of the farmwomen (71\%) spend more than 4 hours a day during shift one whereas, $47 \%$ of the respondents work during shift two. Similarly, in shift three $43 \%$ of farm women work for 2-4 hours a day. Some of the farm women $(6 \%)$ do not participate in the said activity because it was done by the male members at their home. So, they utilize this period in performing other household, childcare and allied activities. 
Table.1 Distribution of sample farm women according to age

\begin{tabular}{|c|c|}
\hline Age & Respondents $(\mathbf{n}=\mathbf{1 0 0}) *(\boldsymbol{\%})$ \\
\hline $\mathbf{2 0 - 3 0}$ years & $50(50)$ \\
\hline $\mathbf{3 0 - 4 0}$ years & $50(50)$ \\
\hline Average age & 31.00 \\
\hline
\end{tabular}

Table.2 Number of family members and children of farmwomen

\begin{tabular}{|c|c|}
\hline Number of Family members & Respondents $(\mathbf{n = 1 0 0}) *(\%)$ \\
\hline $\mathbf{3 - 6}$ & 23 \\
\hline $\mathbf{6 - 9}$ & 36 \\
\hline $\mathbf{9 - 1 1}$ & 21 \\
\hline $\mathbf{1 1}$ and more & 20 \\
\hline No of children & Block kunzer $(\mathbf{n = 1 0 0})(\mathbf{\%})$ \\
\hline $\mathbf{1 - 2}$ & 62 \\
\hline $\mathbf{2 - 3}$ & 24 \\
\hline $\mathbf{3 - 4}$ & 14 \\
\hline Average age of children & 2.26 \\
\hline
\end{tabular}

Table.3 Percentage of time spent on collecting stubbles by farm women

\begin{tabular}{|c|c|c|c|}
\hline \multirow[t]{2}{*}{ Collecting stubbles } & \multicolumn{3}{|c|}{ Respondents $\mathrm{n}=\mathbf{1 0 0}$} \\
\hline & S1 (\%) & $\mathrm{S} 2(\%)$ & S3 (\%) \\
\hline less than $2 \mathrm{hrs} / \mathrm{day}$ & 4 & 12 & 26 \\
\hline 2-4 hrs /day & 19 & 31 & 43 \\
\hline >4 hrs /day & 71 & 47 & 2 \\
\hline No shift & - & 4 & 23 \\
\hline Do not participate & 6 & 6 & 6 \\
\hline
\end{tabular}

Where S1 = Shift one, S2 = Shift two, S3 = Shift three; data in parenthesis shows percentage

Table.4 Percentage of time spent on Cleaning boundaries by farmwomen

\begin{tabular}{|c|c|c|c|}
\hline \multirow{2}{*}{$\begin{array}{c}\text { Cleaning } \\
\text { boundaries }\end{array}$} & \multicolumn{3}{|c|}{ Respondents $\mathrm{n}=100$} \\
\hline & $\mathrm{S} 1(\%)$ & $\mathrm{S} 2(\%)$ & $\mathrm{S} 3(\%)$ \\
\hline Less $<2$ hrs /day & 9 & 8 & 43 \\
\hline 2-4 hrs /day & 21 & 43 & 20 \\
\hline$>4$ hrs /day & 61 & 31 & 4 \\
\hline No shift & - & 9 & 24 \\
\hline Do not participate & 9 & 9 & 9 \\
\hline
\end{tabular}

Where S1 = Shift one, S2 = Shift two, S3 = Shift three; data in parenthesis shows percentage 
Table.5 Percentage of time spent on Nursery Preparation by farmwomen

\begin{tabular}{|c|c|c|c|}
\hline \multirow[t]{2}{*}{ Nursery preparation } & \multicolumn{3}{|c|}{ Respondents $\mathrm{n}=\mathbf{1 0 0}$} \\
\hline & $\mathrm{S} 1(\%)$ & $\mathrm{S} 2(\%)$ & $\mathrm{S} 3(\%)$ \\
\hline less than 2 hrs./day & 6 & 21 & 23 \\
\hline 2-4 hrs. /day & 37 & 34 & 31 \\
\hline$>4$ hrs. /day & 41 & 24 & 2 \\
\hline No shift & - & 5 & 28 \\
\hline Do not participate & 16 & 16 & 16 \\
\hline
\end{tabular}

Where S1 = Shift one, S2 = Shift two, S3 = Shift three; data in parenthesis shows percentage.

Table.6 Percentage of time spent on Seed cleaning by farm women

\begin{tabular}{|c|c|c|c|}
\hline \multirow[t]{2}{*}{ Seed cleaning } & \multicolumn{3}{|c|}{ Respondents $n=100$} \\
\hline & $\begin{array}{c}\mathrm{S} 1 \\
(\%)\end{array}$ & $\begin{array}{c}\text { S2 } \\
(\%)\end{array}$ & $\begin{array}{c}\text { S3 } \\
(\%)\end{array}$ \\
\hline less than $2 \mathrm{hrs} / \mathrm{day}$ & 6 & 19 & 31 \\
\hline 2-4 hrs. /day & 31 & 35 & 25 \\
\hline$>4$ hrs. /day & 61 & 39 & 8 \\
\hline No shift & - & 5 & 34 \\
\hline Do not participate & 2 & 2 & 2 \\
\hline
\end{tabular}

Where S1 = Shift one, S2 = Shift two, S3 = Shift three; data in parenthesis shows percentage.

Table.7 Percentage of time spent on Seed treatment by farm women

\begin{tabular}{|c|c|c|c|}
\hline \multirow[t]{2}{*}{ Seed treatment } & \multicolumn{2}{|c|}{ Respondents } & \multirow{2}{*}{$\begin{array}{c}\mathbf{n}=\mathbf{1 0 0} \\
\text { S3 }(\%)\end{array}$} \\
\hline & $\mathrm{S} 1(\%)$ & $\mathrm{S} 2(\%)$ & \\
\hline less than 2 hrs. /day & 8 & 33 & 52 \\
\hline 2-4 hrs. /day & 32 & 43 & 17 \\
\hline$>4$ hrs. /day & 52 & 10 & 2 \\
\hline No shift & - & 6 & 21 \\
\hline Do not participate & 8 & 8 & 8 \\
\hline
\end{tabular}

Where S1 = Shift one, S2 = Shift two, S3 = Shift three; data in parenthesis shows percentage.

Table.8 Percentage of time spent on Sowing by farm women

\begin{tabular}{|c|c|c|c|}
\hline \multirow[t]{2}{*}{ Sowing } & \multicolumn{3}{|c|}{ Respondents $\mathbf{n}=\mathbf{1 0 0}$} \\
\hline & $\mathrm{S} 1(\%)$ & $\mathrm{S} 2(\%)$ & S3 (\%) \\
\hline less than 2 hrs. /day & 6 & 46 & 22 \\
\hline 2-4 hrs. /day & 34 & 24 & 5 \\
\hline$>4$ hrs. /day & 37 & 7 & 3 \\
\hline No shift & - & - & 47 \\
\hline Do not participate & 23 & 23 & 23 \\
\hline
\end{tabular}

Where $\mathrm{S} 1=$ Shift one, $\mathrm{S} 2=$ Shift two, $\mathrm{S} 3=$ Shift three; data in parenthesis shows percentage. 
Table.9 Percentage of time spent on Pulling out seedlings by farm women

\begin{tabular}{|c|c|c|c|}
\hline Pulling out seedlings & \multicolumn{3}{|c|}{ Respondents $\mathbf{n = 1 0 0}$} \\
\cline { 2 - 4 } & $\mathrm{S} 1(\%)$ & $\mathrm{S} 2(\%)$ & $\mathrm{S} 3(\%)$ \\
\hline less than $\mathbf{2}$ hrs. /day & 2 & 24 & 19 \\
\hline $\mathbf{2 - 4}$ hrs. /day & 22 & 43 & 33 \\
\hline >4 hrs. /day & 76 & 33 & 30 \\
\hline No shift & - & - & 17 \\
\hline Do not participate & 1 & 1 & 1 \\
\hline
\end{tabular}

Where S1 = Shift one, S2 = Shift two, S3 = Shift three; data in parenthesis shows percentage.

Table.10 Percentage of time spent on Transplanting by farm women

\begin{tabular}{|c|c|c|c|}
\hline \multirow[t]{2}{*}{ Transplanting } & \multicolumn{3}{|c|}{ Respondents } \\
\hline & $\mathrm{S} 1(\%)$ & $\mathrm{S} 2(\%)$ & $\mathrm{S} 3(\%)$ \\
\hline less than 2 hrs. /day & 5 & 39 & 28 \\
\hline 2-4 hrs. /day & 25 & 36 & 39 \\
\hline$>4$ hrs. /day & 68 & 19 & 26 \\
\hline No shift & 1 & 5 & 5 \\
\hline Do not participate & 1 & 1 & 1 \\
\hline
\end{tabular}

Where S1 = Shift one, S2 = Shift two, S3 = Shift three;

Table.11 Percentage of time spent on Weeding by farm women

\begin{tabular}{|c|c|c|c|}
\hline \multirow[t]{2}{*}{ Weeding } & \multicolumn{3}{|c|}{ Respondents $\mathrm{n}=\mathbf{1 0 0}$} \\
\hline & $\mathrm{S} 1(\%)$ & $\mathrm{S} 2(\%)$ & $\mathrm{S} 3(\%)$ \\
\hline less than 2 hrs. /day & 19 & 40 & 39 \\
\hline 2-4 hrs. /day & 21 & 45 & 20 \\
\hline$>4$ hrs. /day & 53 & 15 & 9 \\
\hline No shift & 5 & - & 32 \\
\hline Do not participate & 2 & 2 & 2 \\
\hline
\end{tabular}

Where S1 = Shift one, S2 = Shift two, S3 = Shift three; data in parenthesis shows percentage.

Table.12 Percentage of time spent on Harvesting by farm women

\begin{tabular}{|c|c|c|c|}
\hline \multirow[t]{2}{*}{ Harvesting } & \multicolumn{3}{|c|}{ Respondents $\mathrm{n}=\mathbf{1 0 0}$} \\
\hline & S1(\%) & $\mathbf{S 2}(\%)$ & S3(\%) \\
\hline less than 2 hrs. /day & 5 & 4 & 20 \\
\hline 2-4 hrs. /day & 31 & 35 & 47 \\
\hline$>4$ hrs. /day & 64 & 61 & 31 \\
\hline No shift & - & - & 2 \\
\hline
\end{tabular}

Where S1 = Shift one, S2 = Shift two, S3 = Shift three; 
Table.13 Percentage of time spent on Bundling by farm women

\begin{tabular}{|c|c|c|c|}
\hline \multirow{2}{*}{ Bundling } & \multicolumn{3}{|c|}{ Respondents $\mathbf{n = 1 0 0}$} \\
\hline & $\mathbf{S 1}(\boldsymbol{\%})$ & $\mathbf{S 2}(\boldsymbol{\%})$ & $\mathbf{S 3}(\boldsymbol{\%})$ \\
\hline less than 2 hrs. /day & 7 & 7 & 16 \\
\hline 2-4 hrs. /day & 33 & 38 & 40 \\
\hline >4 hrs. /day & 60 & 52 & 36 \\
\hline No shift & - & 3 & 8 \\
\hline
\end{tabular}

Where S1 = Shift one, S2 = Shift two, S3 = Shift three;

Table.14 Percentage of time spent on Threshing and winnowing by farm women

\begin{tabular}{|c|c|c|c|}
\hline \multirow{2}{*}{ Winnowing } & \multicolumn{3}{|c|}{ Respondents $\mathbf{n = 1 0 0}$} \\
\hline & S1 (\%) & S2 (\%) & S3 (\%) \\
\hline less than 2 hrs. /day & 9 & 14 & 31 \\
\hline 2-4 hrs. /day & 46 & 47 & 42 \\
\hline >4 hrs. /day & 43 & 35 & 19 \\
\hline No shift & - & 2 & 6 \\
\hline Do not participate & 2 & 2 & 2 \\
\hline
\end{tabular}

Where S1 = Shift one, S2 = Shift two, S3 = Shift three

Table.15 Percentage of time spent on Bagging by farm women

\begin{tabular}{|c|c|c|c|}
\hline \multirow{2}{*}{ Bagging } & \multicolumn{3}{|c|}{ Respondents $\mathbf{n = 1 0 0}$} \\
\hline & $\mathbf{S 1}(\boldsymbol{\%})$ & $\mathbf{S 2}(\mathbf{\%})$ & $\mathbf{S 3}(\boldsymbol{\%})$ \\
\hline less than 2 hrs. /day & 22 & 17 & 32 \\
\hline 2-4 hrs. /day & 21 & 47 & 36 \\
\hline >4 hrs. /day & 49 & 25 & 9 \\
\hline No shift & - & 3 & 15 \\
\hline Do not participate & 8 & 8 & 8 \\
\hline
\end{tabular}

Where $\mathrm{S} 1=$ Shift one, $\mathrm{S} 2=$ Shift two, $\mathrm{S} 3=$ Shift three;

Table.16 Percentage of time spent on Stocking by farm women

\begin{tabular}{|c|c|c|c|}
\hline \multirow[t]{2}{*}{ Stocking } & \multicolumn{3}{|c|}{ Respondents $n=100$} \\
\hline & S1 (\%) & S2 (\%) & S3(\%) \\
\hline $\begin{array}{l}\text { less than } 2 \text { hrs. } \\
\text { /day }\end{array}$ & 11 & 14 & 36 \\
\hline 2-4 hrs. /day & 20 & 44 & 31 \\
\hline$>4$ hrs. /day & 62 & 29 & 7 \\
\hline No shift & - & 6 & 19 \\
\hline Do not participate & 7 & 7 & 7 \\
\hline
\end{tabular}

Where S1 = Shift one, S2 = Shift two, S3 = Shift three; data in parenthesis shows percentage 
Table.17 Percentage of time spent on Storing of paddy

\begin{tabular}{|c|c|c|c|}
\hline \multirow{2}{*}{ Storing } & \multicolumn{3}{|c|}{ Respondents $\mathbf{N}=\mathbf{1 0 0}$} \\
\hline 0-2 hrs. /day & S1 (\%) & S2 $(\boldsymbol{\%})$ & S3 $(\boldsymbol{\%})$ \\
\hline 2-4 hrs. /day & 13 & 21 & 34 \\
\hline >4 hrs. /day & 28 & 35 & 16 \\
\hline No shift & 41 & 19 & 6 \\
\hline Do not participate & - & 7 & 26 \\
\hline
\end{tabular}

Table.18 Person who helps in transport of paddy

\begin{tabular}{|l|c|}
\hline Person who helps in transport of paddy & Respondents $\mathbf{n = 1 0 0 ( \% )}$ \\
\hline All members of family & 7 \\
\hline Husband & 46 \\
\hline Labour & 20 \\
\hline Both labour \&family members & 11 \\
\hline None & 16 \\
\hline
\end{tabular}

Table.19 Time taken in transport of paddy

\begin{tabular}{|l|c|}
\hline Time taken in transport of paddy & Respondents $\mathbf{n = 1 0 0}(\boldsymbol{\%})$ \\
\hline $\mathbf{1 - 3}$ days & 22 \\
\hline 3-6 days & 60 \\
\hline More than 6 days & 18 \\
\hline Don't transport & - \\
\hline
\end{tabular}

Table.20 Person who guards paddy

\begin{tabular}{|c|c|}
\hline Person who guards paddy & Respondents $\mathbf{n = 1 0 0}(\mathbf{\%})$ \\
\hline All members of family & 40 \\
\hline Myself & 20 \\
\hline Myself and husband & 20 \\
\hline Husband & 20 \\
\hline
\end{tabular}

Fig.1 Showing distribution of family types within district Baramulla of kunzer area

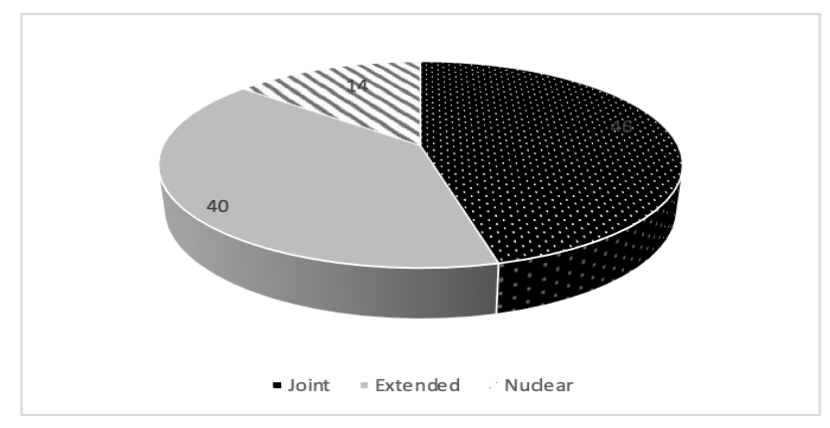


Fig.2 Information related to land holding of families of respondents

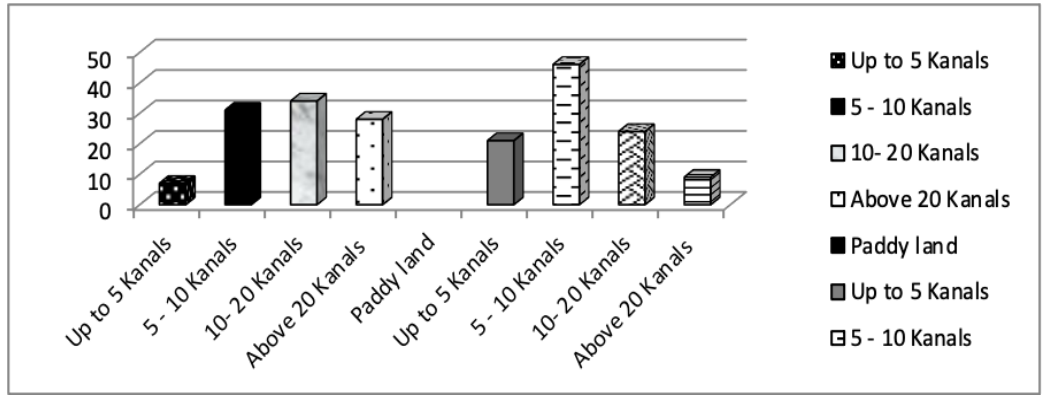

Fig.3 Source of family income of respondents

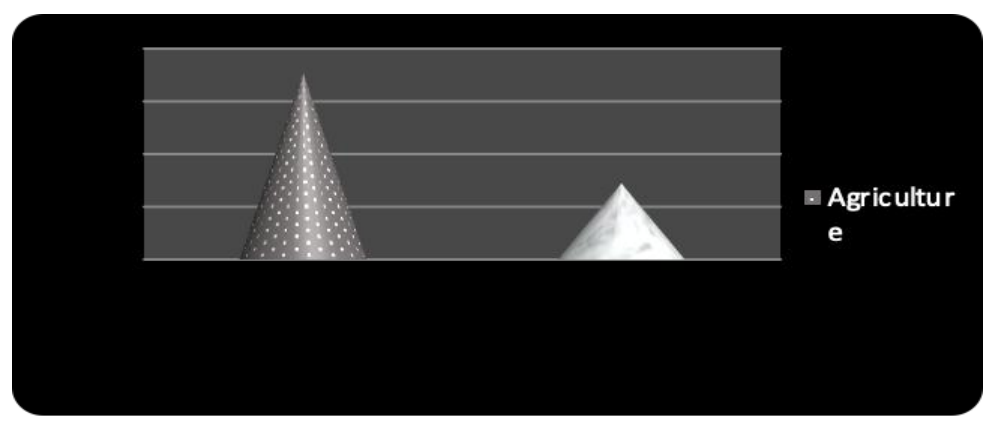

Fig.4 Information of respondents regarding time to go to farm

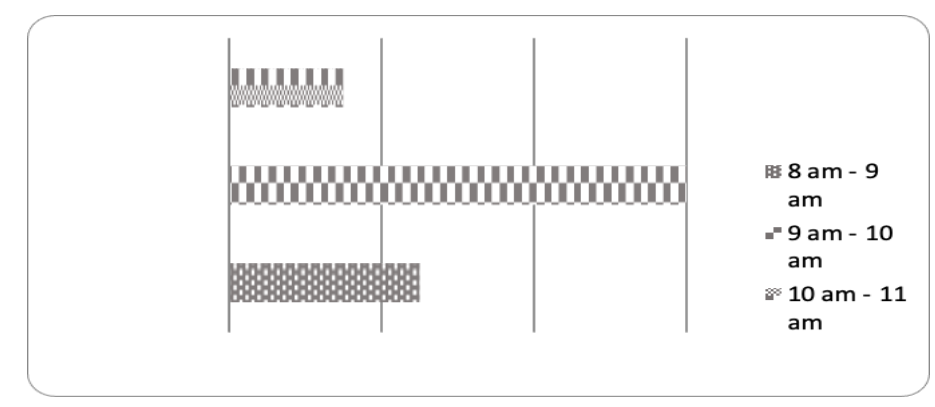

Fig.5 Person who help the respondents in the farm activities

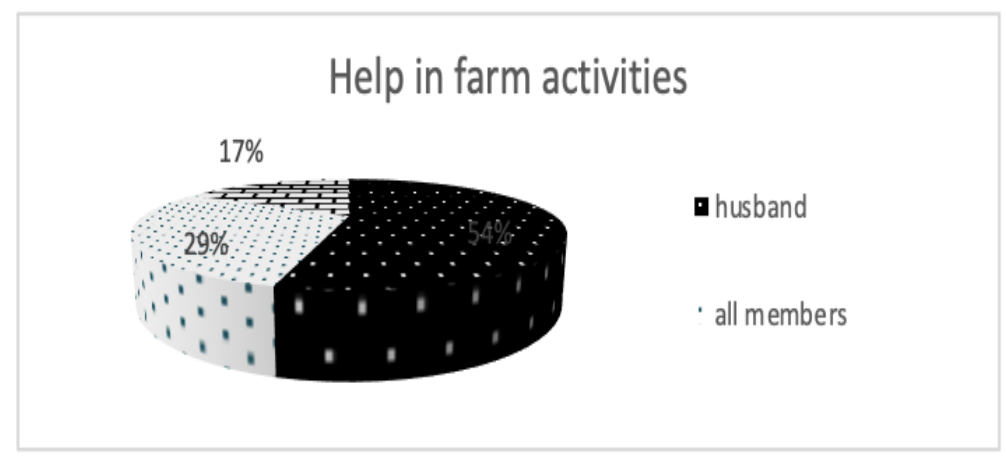


Fig.6 Participation of respondents in Transport of Paddy

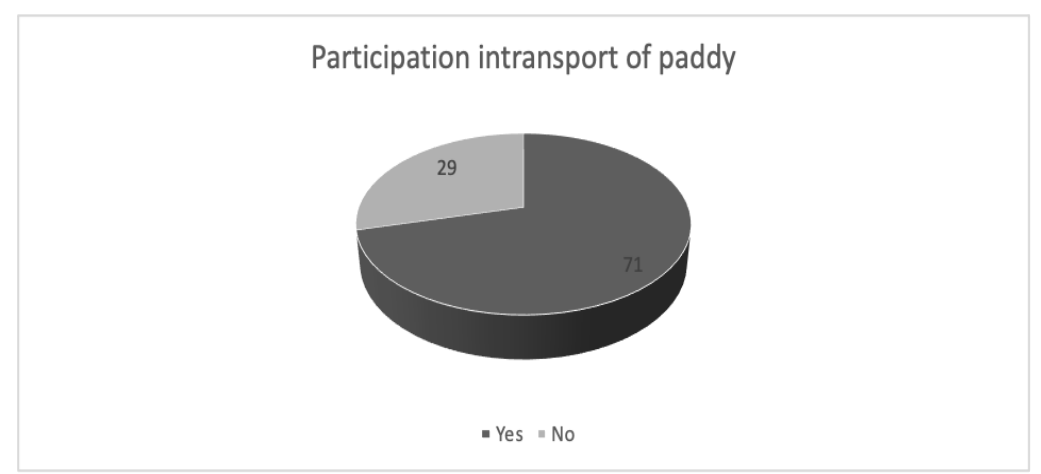

Table. 4 gives information about time spent on cleaning boundaries. The $71 \%$ of farmwomen, spend more than 4 hours a day in shift one, for the farm activity; cleaning boundaries. During shift two, most of the respondents (43\%), spends 2-4 hours a day for the said activity whereas, during shift three, majority of the farmwomen (43\%), spend less than 2 hours a day. Some of the farmwomen did not participate in the activity and some of the respondents does not work during shift three but work only for two shifts for the said activity as shown in the table. Kumar et al (2011) stated that majority of the female perceived drudgery in activities such as preparation of field $(55.00 \%)$, transporting FYM (58.33\%), cleaning of field (63.33\%), seed treatment $(55.00 \%)$ and use of implements with inappropriate shape $(63.33 \%)$.

Table. 5 depicts about the time spent on farm activity Nursery Preparation by farm women. It's clearly visible that majority of the sample (41\%), spend more than 4 hours a day in the said activity. During shift two, most of the respondents (34\%) spend 2-4 hours a day. In shift three, most of them (23\%) work for less than 2 hours a day. Whereas, $37 \%$ of the sample work for 2-4 hours a day during shift one. A percentage of sample $(28 \%)$ did not work during shift three. These women did perform other activities like child rearing during this time period. Some of the farm women $(16 \%)$ did not participate in nursery preparation activity because these activities were performed by the male members of the family.

Table no.6 reveals about the activity seed cleaning. The data reveals that during shift 1 , most of respondents (61\%), work for more than 4 hours a day followed by $39 \%$ who work for 2-4 hours a day but during shift three, majority of the farmwomen $(31 \%)$ work up to 2 hours a day, whereas; $25 \%$ of the sample work for 2-4 hours a day. The average workload of women of low socio-economic status was higher than those of medium, high socioeconomic strata, like in operations like Land preparation, Nursery preparation, Manure, fertilizers application and Intercultural operation as reported by Anshu and Varma (2017).

The information about the seed treatment activity is revealed in table no 1.7. Most of respondents $(52 \%)$ work for more than 4 hours a day during shift one. Maximum number of respondents (43\%) work for 2-4 hours a day in shift two, whereas, $52 \%$ of respondents work for less than 2 hours a day during shift three. Some of the farmwomen does not participate in this activity as the male members perform this activity themselves. The average number of days spent was found to be 2.13 days for seed treatment as stated by Sunita et al., (2009). 
Table no.8 reveals about the activity sowing. Majority of the farm women (37\%), work for more than 4 hours a day, during shift one and $46 \%$ of respondents work for less than 2 hours a day during shift two, whereas during shift three majority of respondents (47\%) didn't work because they perform other activities. Mer (2007) reported that on an average the maximum number of days spent were 28.90 days for sowing and nursery raising.

The information about the activity pulling out seedling activity is revealed in table no.9 All farm women participated in this activity, excluding $1 \%$. During shift one, $76 \%$ farm women work for more than 4 hours a day followed by $43 \%, 33 \%$ of farmwomen who work for 2-4 hours a day in shift two and shift three respectively.

Table.10 reveals that all the respondents participate in transplanting the seedling except $1 \%$ of farmwomen. Majority of farmwomen (68\%) work for more than 4 hours in shift one followed by $39 \%$ each who work up to 2 hours a day during shift two and shifts three. Bimla et al., (2003) worked on women's involvement in agricultural activities at Haryana and reported that involvement of farm women in farm activities was to the extent of $73 \%$, these women faced lots of drudgery in the activities like transplanting, sowing etc. She focused that farm women should be trained in the latest techniques of agriculture to reduce drudgery. Participation of women was observed to be high $(84 \%)$ in the transplanting activity (Sunita et al., 2009). Mer (2007) also revealed that an average number of days spent were 38.20 for transplanting.

The information about weeding is revealed in Table.11. Majority of respondents (53\%), work for more than 4 hours a day, during the shift one followed by $45 \%$ (shift two) for $2-4$ hours a day, whereas during shift three, 39\% farmwomen work for less than 2 hours a day. It was also seen that a good number of farmwomen $(32 \%)$ did not work during shift three.

The average number of days spent was found to be 40.4 for weeding activity and majority of the farm women (79.5\%) spend 40-50 days on weeding of paddy (Sunita et al., 2009). Mer (2007) also revealed that on an average the maximum number of days spent were 46.54 days for inter-culturing and weeding, followed by, 28.90 days for sowing and nursery preparation respectively.

Table no.12 gives a detailed information about harvesting activity. It's clearly revealed that every respondent participates in this activity. Most of sample (64\%) work for more than 4 hours a day during shift one. Similarly, during shift two, $61 \%$ of the respondents work for more than 4 hours a day. During shift 3, most of the respondents (47\%) work for 2-4 hours a day. Sunita et al., (2009) stated that average number of days spent for the activity harvesting are 24.13 days. Sunita et al., (2009) states that time spent hrs/day in harvesting activity was 9.39. According to Mer (2007) on an average the maximum number of days spent were 26.00 for harvesting activity.

Table.13 clearly depicts that all farm women participate in the activity bundling. During shift one, maximum number of respondents $(60 \%)$, work for more than 4 hours a day. Similarly 52\% respondents work more than 4 hours a day during shift two and $40 \%$ of the farmwomen work for 2-4 hours a day during shift three. Sunita et al., (2009) states that an average number of days spent for the activity bundling was 6.15 days.

Table.14 depicts about information regarding threshing and winnowing. During shift one most of farm women (46\%) work for 2-4 hours a day and in shift two $47 \%$ of the farm 
women work for 2-4 hours a day. Most of respondents (42\%) work for less than 2 hours a day during shift three. Only $2 \%$ of the respondents does not perform this activity as done by male members of family. The average number of days spent for threshing was 3.29 days, 2.13 days for seed treatment and only single day was spent for storage of paddy (Sunita et al., 2009). An average of 2.70 days were spent for threshing of paddy Mer (2007).

Table no.15 gives the information regarding bagging of paddy. During shift one, most of respondents (49\%) work for more than 4 hours a day and in shift two, majority of them (47\%) work for 2-4 hours a day. $36 \%$ of respondents work for 2-4 hours a day during shift three. It was also observed that few farm women does not participate in this activity, as performed by the male members in family.

The information about the activity stocking of paddy is given in table no.16. Majority of farmwomen (62\%), work for more than 4 hours a day during shift one. During shift two, maximum number of respondents (44\%), work for 2-4 hours a day. Majority of respondents $(36 \%)$ work less than 2 hours a day in shift three. Few respondents $(7 \%)$ did not perform this work.

Storing is the last farm activity and the information regarding the same is revealed in Table no.17. Majority of respondents $(41 \%)$ work for more than 4 hours a day in shift one. In shift 2, most of respondents (35\%) work for 2-4 hours a day and during shift three, maximum number of respondents $(34 \%)$ work less than 2 hours a day. Many respondents (26\%) did not work during shift three and also $39 \%$ of sample did not perform this activity. snly single day is spent for storage of paddy (Sunita et al., 2009).

Figure. 4 reveals about help received by the respondents in farm activities. Majority of farm women $(54 \%)$ received help from their husbands, $29 \%$ of the sample was helped by all members of family whereas; $17 \%$ of them received help from their other relatives like sister in law, wife of brother in law.

Figure no.5 gives information about transport of paddy. Majority of the respondents (71\%) transport paddy from the field to store. Respondents who do not carry paddy had facilities like some of them had carrier, some used to hire labour etc. So, they did not require performing this activity of their own. Women participation varies between $70-80 \%$ in loading and unloading of grains/straw, transport of farm produce and weighing (Jahan and Khan 2016).

Table.18 reveals about person who help in transporting paddy. Majority of sample (46\%) were helped by their husbands only and $20 \%$ of sample used to hire labour for transportation. As observed only 7\% of respondents received help from all members of family. Also, $16 \%$ of farm women received no help.

Table.19 reveals about the information how many days were taken by farm women in transportation of paddy. Majority of respondents i.e., $60 \%$ took 3-6 days in transportation of paddy to store and $22 \%$ of the sample took 1-3 days for the same. Time taken for transportation was related to various factors like distance from farm to store, quantity of paddy, number of people involved in transportion of paddy and lastly if carrier or vehicle was available for the purpose.

The paddy when transported was stocked and was needed to be guarded with respect to theft. Table 1.20 reveals that majority of respondents $(40 \%)$ were helped by all members of family in guarding of the paddy. $20 \%$ of the sample guarded the paddy themselves, $20 \%$ guarded themselves along with members of family and $20 \%$ were helped 
by their husbands. Few respondents (20\%) didn't perform this activity as their husbands managed it themselves.

In conclusion the majority of sample in present study belonged to age group 25-45 years i.e. young adulthood years and were illiterate. They lived in joint families mostly with minimum six family members and had more than 5 kanals of paddy land with agriculture as main source of income. The respondents worked in three shifts. First shift started from morning to lunch with a short tea break, then second shift after lunch up to tea time in afternoon and last third shift started after tea till evening. Pre harvesting farm activities like collection of stubbles, cleaning of boundaries, sowing, pulling out seedlings, transplanting, weeding were carried out in three shifts spending more than 4 hours in two shifts whereas in third shift they worked for less than four hours a day. Other activities like preparation of nursery, seed treatment was done for more than four hours in shift one, whereas, in other two shifts they worked for less than four hours. During harvesting and bundling, the respondents $(64 \%$ and $60 \%$ respectively) worked for more than four hours a day in first two shifts but in third shift they worked up to four hours. Majority of the respondents (47\%) work for 2-4 hours a day during shift two and during the activity bagging (49\%), stocking (62\%) and storing (41\%) farmwomen work for $\mathrm{s}$ hours in one shift and less than four hours in other shifts. Most of farm women transport paddy in 3-6 days and receive help from their husbands. The paddy was guarded almost by all family members. Post harvesting activities consume lots of energy and time and farm women work a lot during this season. Overall, farmwomen spent 6 hours a day in pre-harvesting activities during farming season, working for more than 4 hours in a shift whereas, they worked for 7 hours a day during harvesting season in the fields with more than 4 hours at stretch. Drudgery was observed to be a main problem in the field activities faced by them so measures should be taken to reduce drudgery, drudgery reducing equipments should be made available to them, also intervention programmes should be performed regarding drudgery reducing instruments and time management, latest agricultural technologies which save time and energy. Measures should be taken to acknowledge their unpaid work, which indirectly adds to economy of nation. It was observed post harvesting activities were more hectic and time consuming.

\section{References}

All Indian Research Coordinated Project. (2001). The National Task Force on Technological Empowerment. New Dehli: ICAR.

Amarante, V. and Rossel, C. (2017). Unpaid Household Work in Latin America: Unfolding Patterns and Determinants. Journal Feminist Economics, 24(1),134.

Anshu*, Dr. Varma SK .International Journal of Scientific and Research Publications, Volume 7, Issue 10, October 2017 pp 36 ISSN 2250-3153 www.ijsrp.org Involvement of Man and Women in Paddy Cultivation Operation.

American Time Use Survey. (2014, June). Bureau of Labour Statistics. Department of Labor Bureau of Labor Statistics, U.S. retrieved from: www.bls.gov/news.release/pdf/atus.pdf.

Bimla,Dilbagi, M.,Kusumrana., and Gandhi, S. (2003). Contribution of Rural Women to Farm Productivity, Social Welfare, 49 (10), 29-31.

Bala, N. (2010). Selective Discrimination against Women in Indian AgricultureA Review. Agric. Rev.31 (3): 224-228

Choudhary, H. and Singh, S., (2003). Farm women in agriculture operations. 
Agricultural Extension Revision. 15 (1), 21-23.

Ganaie, S. AM. And., Bhat., S. (2014). Dynamics of Cropping Land Use Pattern and Status of Food Scenario in Jammu and Kashmir- a Spatio-temporal analysis. Unpublished doctoral. Thesis, Department of Geography and Regional Development, Srinagar: University of Kashmir.

Jahan, N., and Khan, N. (2016) To study the participation of farm women in various agriculture and allied activities. International Journal of Home Science 2(2), 180-186.

Mer, S. (2007). M.Sc. Thesis, CCS Haryana Agric. Univ., Hisa

Singh, D. and Vinay, D. (2013). Gender Participation in Indian Agriculture: An Ergonomic Evaluation of Occupational
Hazard of Farm and Allied Activities. International Journal of Agriculture, Environment \&Biotechnology. 6 (1): 157-168.

Sunita Kumari, Kiran Singh, Manju Mehta and Manju Dahiya. Women involvement in paddy cultivation in haryana state agricultural research communication centre. Agric. Sci. Digest, 29 (4) : 271-274, 2009.

Kumar, B., Gowda V, G., and Khandekar, N. (2011). Time Utilization Pattern and Drudgery of Horticultural Farmers. International Journal of Engineering and Management,2(2), 93-96.

World Bank Group (2011). What We Know About Women in the Economy Today. http:// weconnectinternational.org/en/buyingfor-impact

\section{How to cite this article:}

Afsah Iqbal Nahvi, Adnan Abubakr, Qurazaah Akeemu, Tauseef A. Wani, Mudasir Kirmani, Poonam Sharma and Ruchi Thakur. 2020. Comparative Study of Time Use Pattern in Pre and Post-Harvesting Activities in Himalayan Belt of North India. Int.J.Curr.Microbiol.App.Sci. 9(12): 3524-3537. doi: https://doi.org/10.20546/ijcmas.2020.912.419 